\title{
Hegoaldeko Haur eta Lehen Hezkuntza graduetako ikasleen eleaniztasun-usteak
}

\author{
Beliefs about multilingualism of teacher training students in Hegoalde
}

\author{
Mikel Gartziarena*, Jon Altuna \\ Hezkuntza, Filosofia eta Antropologia Fakultatea \\ Euskal Herriko Unibertsitatea, Donostia, Gipuzkoa
}

LABURPENA: Eleaniztasuna kontu arrunta izan da Europan zehar, eta Euskal Herrian ere ez da salbuespen. Euskal Autonomia Erkidegoan hirueletasuna da jomuga: euskara, espainola eta ingelesa; eta Nafarroako Foru Komunitatean, egoera soziolinguistikoa eta zonifikazioaren mugak tarteko, ere bai. Euskal hezkuntzak euskararen ezagutza, transmisioa eta erabilera hedatzen ditu D ereduaren bitartez, eta globalizazio eta eleaniztasunaren aroan berebiziko erronka aurkezten zaio, euskara ardatz duen eskola eleanitza sortu, bere egin eta proposatzerakoan. Honako azterlan honetan, EAE eta Nafarroako Foru Komunitateko Haur eta Lehen Hezkuntza graduetako ikasleen (etorkizuneko irakasleen) eleaniztasun-usteak ikertzen dira. Ikuspegi kuantitatiboa oinarri, 11 itemeko online-galdetegia diseinatu da, eta 564 gradu-ikasleren usteak jaso dira eleaniztasunaren bueltan. Hala, eskuarteko ikerketak helburu du etorkizunean irakasle izango direnen usteak deskribatzea, euskara erdigune izaki, eta uste horien erroa ikuspegi eleanitzetik ala elebakarretik gertuago ote diren aztertzeko. Etorkizuneko irakasleen usteetan sakontzeak haien jarrerak, irakas-jarduerak eta balioak hobeto ulertzea dakar.

GAKO-HITZAK: Etorkizuneko irakasle-usteak, eleaniztasun-usteak, eleaniztasuna, euskara, unibertsitate-hezkuntza, formazio eleaniztuna.

ABSTRACT: Multilingualism has been common in Europe and the Basque Country is no exception. In the Basque Autonomous Community (BAC) the objective is trilingualism: Basque, Spanish and English; and in the Foral Community of Navarre too, even though the sociolinguistic situation and linguistic zoning. Basque education is the source of knowledge, transmission and use of Basque through the model D. And in the era of globalization and multilingualism a fundamental challenge is presented to Basque education so as to create, develop and implement the approach of a multilingual school centered in the Basque language. This study investigates Early Childhood and Primary School Education degree-students' (future teachers') beliefs about multilingualism in the BAC and the Foral Community of Navarre. Based on quantitative data, an online questionnaire of 11 items was used to gather 564 future teachers' beliefs on multilingualism. The aim of the research is to describe the main characteristics and to analyze whether the root of these beliefs are closer to a multilingual or monolingual perspective. Doing research about teachers' beliefs means better understanding of their attitudes, teaching practices and mindset.

KEYWORDS: Future teachers' beliefs, multilingual beliefs, multilingualism, Basque, University Education, multilingual training.

\footnotetext{
* Harremanetan jartzeko / Corresponding author: Mikel Gartziarena. UPV/EHU. Hezkuntzaren Teoria eta Historia. Elhuyar Plaza 2, Carlos Santamaria Liburutegia (20018 Donostia, Gipuzkoa). - mikel.gartziarena@ehu.eus - https://orcid.org/00000002-0614-6129
}

Nola aipatu / How to cite: Gartziarena, Mikel; Altuna, Jon (2021). «Hegoaldeko Haur eta Lehen Hezkuntza graduetako ikasleen eleaniztasun-usteak». Tantak, 33(1), 165-181. (https://doi.org/10.1387/tantak.22244).

Jasotze-data: 2020/11/16; Onartze-data: 2021/02/12.

ISSN 0214-9753 - elSSN 2444-3581 / (C) 2021 UPV/EHU

(c) (i) $\odot-$ Lan hau Creative Commons Aitortu-EzKomertziala-LanEratorririkGabe 4.0 Nazioartekoa

lizentzia baten mende dago 


\section{SARRERA}

Gaur egungo Europako nazio, estatu eta lurralde gehientsuenetako eskola aurrerazaleenek erro amankomunak dituzte: hezkuntza eleanitzarenak. Europar testuinguruan, munduko makina bat txokotan bezala, hirugarren hizkuntza ikastea esperientzia partekatua da ikasle askorentzat, derrigorrezko eskolatzean nahiz ondorengoetan usadio izanik hirugarren hizkuntza eta gehiagoren irakaskuntza (Cenoz eta Gorter, 2019). Hezkuntzaren curriculum-diseinu eta hizkuntza-politika eleanitzaz gaindi, fenomeno zaharrak eta aldi berean berriak ekarri dituzte globalizazioak, mobilizazioak eta migrazioak. Izan ere, eskolak testuinguru are eleanitzago eta aniztunago bilakatu dituzte, batetik, lekuan lekuko hizkuntza gutxituaren ikaslekua delako eta, bestetik, atzerritik etorritako ikasleek familia-hizkuntza gehitzen diotelako eskola-komunitatearen hizkuntza-ekosistemari (Etxebarrieta et al., 2020).

Munduko eta Europako eskola eleanitzaren errealitatea ez da salbuespen Euskal Herrian, non euskararen ezagutza, transmisioa eta nolabait erabilera ere ahalbidetzen baita hezkuntzaren bitartez. Hala eta guztiz ere, hizkuntza-egoera ez da berdina Euskal Herriko eremu guztietan, muga politikoek eta eratorritako eskumen nahiz herritarren hautuek eragina baitute eleaniztasunaren eratze horretan (Erdocia, 2018; Gorter eta Cenoz, 2017). Horietatik guztietatik, errealitaterik eleanitzena D ereduak eskainiko luke. Hasteko, Euskal Autonomia Erkidegoan (hemendik aurrera EAE) D eredua da nagusi, eta bertan euskara da hizkuntza nagusi, irakatsirik espainola eta ingelesa bigarren eta hirugarren hizkuntza gisa; gainera, Lehen Hezkuntza igaro ondoren, laugarren hizkuntza gisa frantsesa ikas liteke. Nafarroako Foru Komunitateko egoera, aldiz, ez da EAEn azaldu bezalakoa; aitzitik, zonifikazio linguistikoaren araberakoa da eskolatzearen hizkuntza-eredua, izanik hedatuena $D$ eredua eremu euskaldunean eta $G$ eredua eremu misto zein ez-euskaldunean. Iparralden, eskolan irakatsitako hizkuntzei beha, labur esanez, hezkuntza ez da aurreko eremuetan bezain eleanitza, eta, eskumen urriagoak izaki, euskararen eta gainerako hizkuntzen presentzia ere murritzagoa da, frantsesaren presentzia ia erabatekoa izanik.

Oro har, euskara-hiztunen kopuruak gora egin du nabarmen azken 30 urteotan, bereziki, euskararen irakaskuntzan egin den lan eskerga medio. EAEn jazotako hizkuntza-berreskurapenaren gertakaria, ordea, ez da Europan hain arrunta izan, euskara izan baita hizkuntza gutxien artean salbuespen, gainerako hizkuntza gutxituek galerak pairatu baitituzte hiztun kopuruetan (Amonarriz eta Martinez de Lagos, 2017; Garcia et al., 2017). Etorkizunari begira, zenbait palankaren beharra aipatzen dute Amonarrizek eta Martinez de Lagosek (2017) euskararen normalizazioan, hala nola herrietako egitura euskaltzaleak saretzea, hizkuntza-politika doitzea, epe luzerako plangintzak antolatzea eta egituratzea. Ikasleen identitatea, ezagutza eta hizkuntza-erabilera izan dituzte aztergai L. Garcia et al.-ek (2017), eta, 
oro har, haien ikerketa-ondorio nagusietakoa honako hau da: ikasle guztiek jarrera positiboa dutela euskararekin, baina, euskara maila altua izanik ere, hizkuntzaren erabilera ez dagoela ziurtaturik. Are, ikasleek euren burua euskalduntzat duten arren, identitate etnolinguistikoa ez da soilik euskararekin lotzen; aitzitik, espainolarekin ere lotzen dute beren identitate etnikokulturala. Euskara, hezkuntza eta soziolinguistika uztarturik, Aiestaranen (2012) doktorego-tesia argigarria da; izan ere, hainbat ezaugarriren artean, hark ondorengo bi tentsioguneak nabarmendu zituen Arabar Errioxan, Euskal Herriko beste testuingurutara estrapola litezkeenak: batetik, euskara lur eremu jakin baten azaleko kultura-ondare hutsa izatea, hots, folklorea; eta, bestetik, identifikaziorako hizkuntza bizia, erabilera sozialekoa eta hein batean lehenetsia.

Hezkuntza eleanitzaren azterketara itzulita, egun, hizkuntzak elkarrengandik bereizirik irakasteko egitasmo pedagogikoak agorturik daude, eta formula berrien bila ari dira adituak hizkuntzen ikaskuntza holistikoagoa hauspotzeko, eta, eleaniztasunaren abantailak probesturik, hizkuntza minorizatuak indarberritzeko (Cenoz eta Gorter, 2014; Conteh eta Meier, 2014; May, 2013). Honako ikerlanak etorkizuneko irakasleak izango diren Hegoaldeko Haur eta Lehen Hezkuntza graduetako ikasleen eleaniztasun-usteak arakatzea eta deskribatzea du helburu. Izan ere, etorkizuneko irakasleek dituzten usteek berebiziko garrantzia dute, are handiagoa uste horien oinarriak. Hain zuzen ere, uste horien erroa ezagutuz gero, trebatze-ikastaroak berariaz molda eta egoki litezke, etorkizunerako gizarte gisa jarritako helburu linguistiko eta hezitzaileak erdiesteko. Hari horretatik tiraka, esku arteko ikerketak asmo bat du: euskara ardatz izanik, Hegoaldeko Haur eta Lehen Hezkuntzako gradu-ikasleek eleaniztasunari buruz dituzten usteak ezagutzea. Horretarako, bi helburu zehatzagotan adarkatzen da: lehenengoa, etorkizuneko irakasleen eleaniztasun-usteen ezaugarri bereizgarrienak deskribatzea; bigarrena, etorkizuneko irakasleen eleaniztasun-usteak, oro har, indarrean dauden teoria eleanitzen esparruan duten kokalekua zehaztea; hots, irakasleen usteak ikuspegi elebakarretik ala eleanitzetik gertuago kokatzen ote diren jakitea.

\section{OINARRI TEORIKOA}

Honako atal teorikoan eleaniztasunari buruzko zenbait nozio orokor emango dira. Ondoren, gaur egun eleaniztasuna gorpuzten duen euskarri teorikoak izendatu eta garrantzitsuenei buruzko azalpenak emango dira. Jarraian, usteak definituko, eta hezkuntzarekin duten eragina aztertuko da. Gero, eleaniztasuna eta usteak, bi kontzeptuok, bateratu eta ikerketarik garrantzitsuenak ekarriko dira, ardatz izanik Lehen eta Haur Hezkuntza graduetako ikasketak burutzen ari diren etorkizuneko irakasleek eleaniztasunaren inguruan dituzten usteak. 
Elebakarra definitzeko adiera ezagun dugu; baina eleaniztuna definitzerakoan desadostasunak eta ikuspuntu kontrajarriak izan dira nagusi. Horietatik guztietatik, historian zehar, idealizazio lortezina egon da oinarrioinarrian hiztun eleanitza definitzeko garaian. Hain zuzen ere, eleaniztunari atxiki izan zaio dakizkien hizkuntza guztietan natiboaren - elebakarraren - maila ezin erdiestea, uste horretan oinarriturik mito elebakarra (Cenoz eta Gorter, 2015). Hiztun eleanitzaren idealizazio eskuraezin horrek eragin negatiboa izan du eleaniztasuna ulertzeko garaian, eta urte luzez literatura akademikoak prisma elebakarretik ikertu izan du eleaniztasuna, agerian utzirik eleaniztuna hiztun gabezidun, ez-oso, izatearen ustea (Cenoz eta Gorter, 2014; Grosjean, 2010). Hiztun bat eleanitza ote den zehazteko ulerkera ezberdinak daude. Irizpide ezagunenen artean, hizkuntza bakoitzean hiztunak duen gaitasun-maila eta hizkuntzak jasotzeko momentuak dira: aldiberekoa, hizkuntzak batera jaso baditu; eta ondoz ondokoa, lehenengo hizkuntza finkatu eta ondoren besteak etorri badira. Eleaniztuna ikuspegi hertsiekin zehazteak arazoak dakartza; izan ere, mailakatze horrek eleaniztunaren hizkuntzen artean orekak eta desorekak baitakartza; hau da, eleaniztunak dakizkien hizkuntza guztiak banaka hartu eta isolatzen saiatzea, ohikoa izanik eleaniztunaren sistema linguistiko saretua alboratzea (Cenoz eta Gorter, 2019; García, 2009; García eta Wei, 2014). Eskuarteko ikerlanak eleaniztasuna osotasun gisa ulertzen du, hizkuntzei buruzko ezagutzak definitzen baitu eleaniztuna, izanik haren hizkuntza-ezagutza berezkoa bezain errepikaezina (Cenoz eta Gorter, 2014). Hala, nola ezberdindu eleaniztuna elebakarrarengandik? Guretzat, bi hizkuntzaren ezagutza eta erabileran oinarrituko litzateke, izanik elebiduna eleaniztasunaren adierarik txikiena (Cenoz, 2009).

Eleaniztasunaren gaur egungo ikuspegi integratzaile eta abegikorra ulertzeko, Grosjean-en (1985) ekarpena mugarri izan da; izan ere, haren Hizkuntzen Ikuspegi Frakzionala ikerlana argigarria izan da hizkuntzak banaka, elkarrengandik bereizirik, irakatsi eta erabili izan direla ohartarazteko. Europan eta munduan, hizkuntzak elkarrengandik bereizirik, isolaturik, irakatsi dira, eleaniztunak dituen ezaugarri eta ikasprozesuei jaramonik egin gabe. Honakoan ere, Euskal Herria ez da salbuespen, eta, oro har, hizkuntzak ikuspegi elebakarrarekin irakasten dira, eredu eleanitza bultzatzen ari direlakoan. Hain zuzen ere, eredu elebakarra eredu eleanitzera lerratu nahi da; baina egungo eredu eleanitzak erro elebakarrekoa izaten jarraitzen du, hizkuntzen arteko koordinazio eta zubi-lan urriarekin, eleaniztasunak eman ditzakeen abantailei ezaxola eta ikaslea eskolaz kanpoko behar linguistiko eleanitzetan trebatu gabe (Cenoz eta Gorter, 2014; Conteh eta Meier, 2014; May, 2013). Halaber, euskal eskola eleanitz askoren ikuspuntua elebakarra da, irakasten den hizkuntza bakoitzean berezko hiztun izatera bultzatzen baitira ikasleak. Eleaniztun izatea abantaila gisa ulertzen da Europan, eta, oparotasunak oparotasun, eleaniztasuna hizkuntzak ikasteko kondizio katalizatzaile gisa ulertzen (Cenoz, 2013; Jessner, 
2008, 2016; Maluch eta Kempert, 2017); alde batetik, ikaslearen funtzio kognitiboak zorrozten eta trebatzen dituelako (Barac et al., 2014; Kalashnikova eta Mattock, 2014; Moodie, 2016; Thomas-Sunesson et al., 2016) eta, bestetik, ikaslearen abilezia metalinguistikoa handitu eta hizkuntzak ikasteko bide lasterrak irekitzen dituelako (Bialystok, 2007; Reder et al., 2013). Hau da, eleaniztasuna, bigarren mailako ezaugarri kontsideratu beharrean, erdigunera ekarri beharko litzateke, haren berezkotasunak erdigune izanik, ikuspegi eleanitzean oinarritutako egitasmoak aurrera eramateko.

Ikerlanaren euskarri teorikoak bi eredu nagusi izango dira, gaur egun Europako proposamen eleanitzen erreferentzia direnak: The Multilingual Turn (Aldaketa Eleanitza) eta Focus on Multilingualism (Ikuspegi Eleanitza). Eleaniztasunaren etengabeko bilakaeran, askoren artean, mugarri izan da Conteh eta Meier-ek (2014) eta May-k (2013) izen berberarekin bataiatu zuten ekarpen-parea: The Multilingual Turn ekarpena. Eleaniztasuna etengabeko bilakaeran eta eraldatze-prozesuan ari da, eta ekarpenak baliagarri izan dira ikuspegi integratzaileago, irekiago eta malguagoetara mugitzeko; eleaniztasuna ulertzeko eran ez ezik, ikerketa-ikuspegian ere eragina izan baitu. Bi lanek eragina izan dute eleaniztasunaren teorietan, pedagogietan eta irakas-jardunetan, eta, orobat, bigarren eta atzerriko hizkuntzaren irakaskuntzan. Irakas-jardun elebakarrak arbuiatzen dituzte, eta praktika eleanitzak erdigune izango dituzten pedagogia eleanitzak proposatzen dituzte. Azken finean, ikasle eta irakasle eleaniztunei zuzendutako hausnarketak dira, eleaniztasunari ekarpen egin eta berdintasuna, gizarte-kohesioa, atxikimendua eta ahalduntzea helburu. Izan ere, eleaniztunaren hizkuntza-jardunak ez dira zerbait zurrun-hertsi gisa kontsideratzen, ikuspuntu elebakarrak ordura arte egin izan duen gisan; kontrara, hizkuntzari ezaugarri likidoa eransten diote, eta hizkuntzak garunean konpartimentutan bereizi baino osotasunean ulertu, funtzio sozialerako helburuarekin.

The Multilingual Turn eredua oinarri harturik, Cenoz eta Gorter-en (2014) Focus on Multilingualism eredua izango da hizpide, hizkuntzak ulertzeko erarekin eta ikerlanaren ezaugarriekin bat egiten duelako. Ikuspegiak, Aldaketa Eleanitzaz gain, bat egiten du beste bi teoria multzorekin: Blackledge eta Creese-ren (2010) Elebitasun Malguarekin (Flexible Bilingualism-ekin) eta, bigarrena, García-ren (2009) Translanguaging-ekin. Focus on Multilingualismek ez ditu hizkuntzak erdigunetzat: hiztun-eleanitzak dira protagonista zilegi bakar. Izan ere, eleaniztunak hizkuntzak helburu komunikatiboaren menpe darabiltza, hizkuntzen arteko muga zurrun teorikoei bizkar emanda, hizkuntzak ez baitira objektu, ez baitira nahieran aldagarri. Hiztunak hizkuntzei buruz duen ezagutza oro da baliagarria, eta hizkuntza-ezagutza osoa berezko baliabide da komunikazio-helbururako. Erreferentzia, beraz, eleaniztunaren jarduna litzateke, eta honako hirurak lirateke Ikuspegi Eleanitzaren dimentsio nagusiak: lehena, Hiztun Eleani- 
tza; bigarrena, Hizkuntza-Ezagutza Osoa; hirugarrena, Testuinguru Soziala. Hiztun Eleanitzaren dimentsioak uko egiten dio eleaniztuna hiztun elebakarren batuketa hutsa izateari, hiztun herren gisa kontsideratzen baita; eta ereduak eleaniztuna hiztun oso eta komunikazio-aukera handiagoaren jabetzat dauka, dakizkien hizkuntzen artean ibiltari, testuingurua arakatu eta haren beharrizanetara hizkuntzarekin egokitzeko gaitasun erabatekoarekin. Hori gutxi ez-eta, Hiztun Eleanitzak bere Hizkuntza-Ezagutza Osoa darabil, hizkuntzek osatzen duten sistema linguistiko bateratu konplexua, komunikazio -helburuak betetzeko eta hizkuntzaren ikaskuntza-prozesua katalizatzeko. Eta azkenik, Testuinguru Soziala izango litzateke aurreko bi dimentsioak egokituko diren eremua, Hiztun-Eleanitzaren Hizkuntza-Ezagutza Osoa koordinatu eta Testuinguru Sozialaren ezaugarrietara, ekintza komunikatiboaren mesedetara egokitzeko. Izan ere, eleaniztunak hizkuntzak era jakinean egokitzen ditu hizketa-lagunaren hizkuntza-ezagutzara, testuingurura: nola formalera hala informalera. Eleaniztasuna, zorionerako edo zoritxarrerako, hori baino askoz ere konplexuagoa da.

Eleaniztasuna konplexua baldin bada, usteak ez dira inolaz ere sinpleak, eta, hori dela-eta, hainbat definizio eman izan zaio, aditu bezainbeste kasik, sarritan kontzeptua argitu baino lanbrotu eta nahastu egin dutenak (Pajares, 1992). Usteak hizkuntza-irakaskuntzaren giltzarri kontsideratu izan dira, irakas-jardun kontziente eta inkontzientetan islaturik (S. Borg, 2015). Usteak irakaslearen jarduna zuzentzen duten balio-sistematzat onartzen dira, norberaren egiak direnak, testuingurua hauteman eta errealitatearekin dialektikan (Zheng, 2013), presente egonik irakaslearen hautu pedagogikoetan (Kalaja eta Barcelos, 2019). Azken buruan, irakasleen usteak ikertzea hizkuntza-irakaskuntza eta -ikaskuntzan aurrera egitea da, eraginkortasuna hobetzeko, formazioa pertsonalizatzeko eta curriculuma egokitzeko (Gilakjani eta Sabouri, 2017).

Etorkizuneko irakasleen usteak eta eleaniztasuna ikertu duten ikerketa esanguratsu asko dago. Horien artean, Portolés eta Martí-ren (2018) ikerketa nabarmendu beharko litzateke. Valentziako Komunitatean eginiko ikerketa da, etorkizuneko irakasleen eleaniztasun-usteak ardatz dituena eta bertako hizkuntza gutxitua ikertzen duena eleaniztasunaren talaiatik. Oro har, ikerketa-emaitzek erakusten dute etorkizuneko irakasleen eleaniztasun-usteak positiboak eta abegikorrak direla eleaniztasunarekiko eta hizkuntza gutxituarekiko, errotutako zenbait uste elebakar azaldu arren. Uste elebakar horietatik, esanguratsua da ikasleek uste dutela eleaniztunak maila oso altua behar duela hizkuntza bakoitzean, beterik arestian azaldutako mito elebakarra. Horrekin batera, deigarria da ikasleek hizkuntza-ikaskuntza goiztiarrean sinesten dutela, hots, zenbat eta lehenago ikasi, orduan eta arrakasta handiagoa. Azkenik, ikerlanak goraipatzen du ikasleen usteen formazioan eragin positiboa duela esku-hartze goiztiarrak eta irakasle-eskoletako graduetan giltzarri dela hasierako etapetan usteak identifikatu eta horien gaineko lanketa eleanitza egitea. 
Formazio-ikastaroek eleaniztasun-usteetan duten eragina ikergai izan da beste ikerlan esanguratsuetan ere. Horietan eztabaidatu izan da formazio-ikastaroek usteen aldaketan izan dezaketen eragina. Ikerlanen artean, Peacock-en (2001) ikerketak azpimarratzen du usteak gradualki alda litezkeela, baina ez dagoela alde esanguratsurik; hori bai, adituaren ondorio nagusietako bat etorkizunari begira egina da: usteak aldatzeko, formazioak gradu-ikasketaren hasieran eman behar dira, uste negatibo horiek errazago zuzentzen direlako; edonola ere, zenbait uste erresistentzia-maila handikoak dira eta nekez alda litezke. Nolanahi ere, etorkizuneko irakasleen prestakuntzaren garrantzia handia da, eta neurtu izan da trebatze-ikastaroen ahalmena usteak aldatzeko orduan. Formazio-ikastaroak bi bide adierazten ditu: bat, zenbait usteren elaborazioa eta heltzea ematen da; bi, zenbait uste gogorragoak, iraunkorragoak eta aldakaitzagoak dira (M. Borg, 2005). Formazio-ikastaroen eraginean sakonduz, Cabaroglu eta Roberts-en (2000) ikerlanak usteen eboluziorako aukera eta moldatzeko gaitasuna azpimarratzen ditu. Sheridan-ek (2016) antzeko emaitzak eskuratu ditu, eta etorkizuneko irakasleek jasotzen duten gradu-ikasketaren formazio-balioa neurtu du, urtez urte, graduko lau urteetan zehar. Haren ikerketa-ondorioa garbia da: etorkizuneko irakasleen usteak molda litezke graduak irauten dituen lau urteetan zehar, eta etapa hori erabakigarria da usteetan eragin eta etorkizuneko irakas-jardunak hobetzeko. Formazio-ikastaroen eragin hezigarria baieztatzen du Fischer eta Lahmann-en (2020) ikerlanak, usteak eleaniztasunean hezi baitaitezke. Espreski sorturiko ikastaroek ez ezik, praktikaaldiek usteak eguneratzen duten eragina azpimarratzen du Yuan eta Leeren (2014) lanak; eta, halaber, usteen aldaketak errazteko ezinbesteko dela ikasleari testuinguru ireki eta babeslea sortzea.

Etorkizuneko irakasleen usteak, orain irakaskuntza-ikasketetan murgildurik dauden ikasleen usteak, ikergai izan dira. Askoren artean, azpimarragarria dira Inceçay-ren (2011) ikerketa-emaitzak: etorkizuneko irakasleek hirugarren hizkuntzari buruz dituzten usteek sekulako eragina dutela eleaniztasunari buruzko usteetan. Aldiz, Jeoffrion et al.-en (2014) ondorioek adierazten dute eleaniztasunari buruzko usteen garapenean eragin handia duela zenbat hizkuntza eta zer-nolako sakontasun-mailan ikasten diren; hots, eleaniztunago izateak eta hizkuntzetan ezagutza areagotzeak eragin positiboak dituela eleaniztasun-uste positiboagoren garapenean. Moodie-ren (2016) lanak baieztatzen du ikasle bezala jasotako esperientzia guztiak, haur hezkuntzatik hasi eta goi-ikasketak jaso eta harago, eragina duela usteen konformazioan, eta ikasleak jasotzen duen ereduaren eta esperientzia multzoaren arabera moldatzen direla haren usteak. Ereduak eredu, etorkizuneko irakasleentzat biziki esanguratsuak dira irakasle txarrak kontsideratzen dituztenak, esperientziek galbahe moduan funtzionatzen baitute etorkizuneko irakaslearen uste-sisteman zer ez izan eta nola ez irakasteko. 


\section{METODOLOGIA}

Honako atal honetan, datuen jasoketan erabilitako materialak eta instrumentuak deskribatuko dira, baita datuen prozesamenduaren ekinbideko zehaztapenak eta laginaren datu erakusgarrienak emango ere. Gogoan hartu, ikerketaren habe teorikoa arestian azaldutako Ikuspegi Eleanitza dela (Cenoz eta Gorter, 2014).

Lehenik eta behin, zehaztu beharra dago ikerketan erabiliko zen metodoa; izan ere, eskuarteko ikerlanak jomuga du Hegoaldeko Haur eta Lehen Hezkuntzako gradu-ikasleen eleaniztasun-usteen ikerketa deskribatzailea egitea. Horretarako, ikuspuntu kuantitatiboa erabili da, eta eragiketa estatistiko deskribatzaileen bitartez etorkizuneko irakasleen eleaniztasun-usteak behatu dira horien ezaugarriak ezagutzeko. Era berean, usteen izaera positiboa ala negatiboa oten den ikertu nahi da. Hori zelabide, izaera biko ikerketa diseinatu da: esploratzailea eta deskribatzailea. Ikerketa esploratzailea hautatu izanaren atzean gradu-ikasleen eleaniztasun-usteak lehen hurbilpen gisa analizatzeko asmoa dago; aldiz, deskribatzailearenean, misioa argia da: esploratutako errealitatearen deskribapena egitea (Dendaluze, 2002). Orriotako azterlana ikerketa sakonago eta luzeago baten zati da, eta ondorengo lerroetan ikerketa-lagina deskribatuko da, datuen jasoketarekin, materialekin eta baliabideekin batera. Ikerketa-ekinbidea ere azalduko da, emanik datuen prozesamenduei buruzko xehetasunak eta partaideen anonimotasuna eta parte-hartze librea zaintzen erabilitako bidea.

Ikerketan datuak jasotzen erabilitako lanabesa ikerlariek prestaturiko online galdetegia izan da, aurretiaz, DREAM ikertaldean (Donostia Research group on Education and Multilingualism-en) erabilitako galdetegietan oinarriturik eta segida emanik (Aiestaran, 2012; Arocena, 2017). Online galdetegiaren egitura itxia da, eta 0tik 4rako (0: Erabat Kontra; 4: Erabat Alde) Likert-eskala erabili da eleaniztasuna neurtzeko 11 itemak azaltzeko. Galdetegia diseinatzeko, sortzeko eta partaideei hedatzeko, Encuestafácil programa erabili da (https://www.encuestafacil.com/), Euskal Herriko Unibertsitateak ikerlariei eskuragarri uzten dien baliabidea. Partaideek galdetegirako sarbidea e-mail bidez jaso dute, ikerketa-gonbidapenetan. Galdetegirako esteka 2018/03/14an aktibatu da eta 2018/05/02an desaktibatu. Ikerketak UPV/EHUko Etika Batzordearen ikerketarako onespena jaso du (identifikazio-kodea: M10_2017_143), eta proposatutako ekinbidea jarraitu da ikerketan zehar.

Datuen jasoketarako, lehenik eta behin, ikerlariak harremanetan jarri dira Haur eta Lehen Hezkuntza graduak eskaintzen dituzten fakultateetako dekanoekin, e-mailez, EAEko eta Nafarroako Foru Erkidegoko unibertsitateetan. Kontaktatutako dekano guztiek onartu dute ikerketan parte hartzea, eta, hortaz, ikerketa-gonbidapenak, egiaztagiriak eta onarpen-dokumentuak bidali dira, partaideen onespena jasotzeko. Hala, onarpen-agiriak sinatu eta 
ikerlariei bidali zaizkie. Dekanotza taldeko kideek tartekari-eginkizunak hartu dute, ikerlariaren eta partaideen arteko kontaktua ekiditeko, eta ikerketan parte hartzeko gonbidapena email bidez bidali diete fakultateko dekanoek gradu-ikasleei, utzirik haien esku parte hartze librea. Datuak jaso ostean, prozesamendua SPSS programa estatistikoarekin burutu da, eta analisi estatistiko deskribatzaileak egin dira arestian aipatutako helburuak lortzearren.

Orotara, 564 galdetegi jaso dira oso-osorik beteak, eta horietatik 108 $(\%$ 19,1) Haur Hezkuntzako graduko ikasleak dira, 446 (\% 79,1) Lehen Hezkuntzakoak eta $10(\%$ 1,8) irakaskuntzarekin erlazionaturiko beste ikasketa batzuetan murgildurikoak. Parte-hartzaileen kopuru osotik, 117 (\% 20,7) Euskal Herriko Unibertsitatean ikasten ari dira Arabako canpusean, $131(\%$ 23,2) Bizkaiko canpusean eta 93 (\% 16,5) Gipuzkoakoan. Mondragon Unibertsitatetik 29 (\% 5,1) gradu-ikasleren datuak jaso dira, $42(\%$ 7,4) Nafarroako Unibertsitate Publikoan, 110 (\% 19,5) Deustoko Unibertsitateko Bilboko fakultatean eta $42(\% 7,4)$ Donostiako fakultatean. Sexuari dagokionez, 435ek $(\% 77,1)$ emakume aukera adierazi dute, $123 \mathrm{k}$ $(\% 21,8)$ gizonezkoa eta $6 \mathrm{k}(\% 1,1)$ ez-binarioa. Laginaren batezbeseko adina 21,2 urtekoa da, izanik 18 urtekoa parte-hartzailerik gazteena eta 46koa edadetuena. Gradu-ikasleen urte akademikoari beha, 119 (\% 21,1) lehenengo urtean ari dira, $199(\% 35,28)$ bigarrenean, $126(\% 22,34)$ hirugarrenean, $97(\%$ 17,2) laugarrenean eta $23(\% 4,08)$ ikasturte gehigarrietan. Lehenengo hizkuntzari begira, 203k (\% 36) euskara adierazi dute, $249 \mathrm{k}(\% 44,1)$ espainola, $2 \mathrm{k}(\%, 4)$ ingelesa, 108k $(\%$ 19,1) euskara eta espainola, batek (\% 2) euskara, espainola eta ingelesa izanik eta beste batek (\% 2) zerrendan ageri ez den beste hizkuntza bat adierazirik.

Emandako datu deskribatzaileak alde batera utzirik, aldagai konposatu bat sortu da eleaniztasun-uste horien batezbestekoarekin, uste orokor positiboak ala negatiboak ote diren kalkulatzeko. Helburu horrekin, 11 itemen fidagarritasun-kalkuluak egin dira, Cronbach alpha balioetan oinarriturik. Dimentsio-murriztapenaren kalkuluak egin eta 6,8,9 eta 10 itemak kanpoan utzi dira batezbestekoa kalkulatzeko, izanik 7 itemez osatutako aldagai berriaren Cronbach alpha balioa .61ekoa, baleko neurria izanik kalkuluak egin ahal izateko (Taber, 2018). Eleaniztasun-usteen aldagai berriaren batezbesteko balioa 0 eta 4 artean kokatzen da, eta balio altuak uste-sistema eleanitzagoa islatuko luke, eta baxuak uste-sistema elebakarragoa.

\section{EMAITZAK}

Honako atal honetan, metodologia atalean azaldutako bi kalkulu nagusien datuak argitara emango dira: batetik, eleaniztasun-usteen aldagai berriaren batezbestekoa, eta, bestetik, galdetegietan jaso diren 11 itemen datu 
estatistiko deskriptiboak, hurrenez hurren. Beraz, esan bezala, eleaniztasuna neurtzeko sortutako aldagai berriaren ( 7 itemez osatua) batezbestekoa kalkulatu da, izanik 2,77 haren balioa, 0 eta 4 balio-mugen artean eta islaturik Haur eta Lehen Hezkuntza graduetako ikasleen eleaniztasun-uste positiboak.

Ondoren, eleaniztasun-usteen datu estatistiko deskribatzaileak neurtu dira, gradu-ikasleen adostasunaren arabera sailkaturik. Frekuentzia maiztasunak 1. irudian daude ikusgai, eta honako hurrenkeran kategorizatu dira: (0: Erabat Kontra, EK; 1: Kontra, K; 2: Ez Alde Ez Kontra, EAEK; 3: Alde, A; 4: Erabat Alde, EA). Ikusi daitekeenez, datuen hurrenkera item bakoitzarekiko adostasun-mailan oinarritzen da, izanik hasierako itemak adostasun-mailarik handiena batzen dutenak eta azkenak desadostasunmaila zabalena jasotzen dutenak (ikus 1. irudia).

Lehenengo eta behin, adostasun-maila handiari so eginez, hiru dira lehen begi-kolpean esanguratsuenak. Hamaika item horietatik, 8. itema da onarpen-mailarik handiena jaso duena: «Hizkuntzak zenbat eta lehenago ikasi, orduan eta arrakasta handiagoa» (EA: 30; A: 40,4). Bigarrena, eta kasik lehenengoaren pare, 5. itema: «Elebidunak erraztasun handiagoa dauka hirugarren hizkuntza ikasterakoan» (EA: 22,7; A: 47,2). Eta hirugarren postuan 1. itema: «Eleanitzek errazago ikasten dute, erraztasun kognitiboak dituztelako» (EA: 19,5; A: 43,4).

Beste ertzean, adostasun-mailarik baxuena jasotako itemen artean, hirutan behatu ahal izan dira desadostasun-maila handiak. Hasteko, graduikasleek 4. itemarekin, «Eleaniztasunak ikaslearen eskola-porrota ekar dezake»rekin (EK: 51,8; K: 35,6), erakutsi dute kontrako iritzirik indartsuena. Ondoren, 2. itemarekin: «Eleaniztasunak hizkuntzaren garapen berantiarra ekar dezake» (EK: 42,6; K: 37,4). Eta hiruren artean azkena, 6. itemarekin: «Ikasle eleanitzak ezin ditu hizkuntzak elkarrekin nahastu» (EK: 17,4; K: 44,3). Era berean, beste hiru itemek desadostasun-maila handia jaso zuten, nahiz eta aurreko hirurek jasotakoa baino apalagoa izan. Gradu-ikasleen erdiak baino gehiagok adierazi du desadostasuna 10. itemarekiko: «Euskara baino erabilgarriagoak diren hizkuntzak irakas daitezke» (EK: 33,7; K: 25,4). Era berean, pareko desadostasuna jaso da 3. itemarekin «Eleaniztasunak identitate arazoak sor ditzake»rekin (EK: 20,9; K: 37,8 ) eta 7. itemarekin «Hirueletasunak arriskuan jartzen du hizkuntza gutxituaren iraupena» (EK: 19,9; K: 35,8).

Lehen eta Haur Hezkuntzako gradu-ikasleek bi itemekin erakutsi dute aldeko eta kontrako iritzirik orekatuenak, izanik, halaber, jarrera neutraleko aukera partaide gehien batu dituena. Item horiek honako biak dira: 9. «Onuragarria da hiru hizkuntzak klase eta ikasgai berean tartekatzea» (EA: 15,1; A: 26,2; EAEK: 36,7; K: 17,4; EK: 4,6) eta 11. «Hirugarren hizkuntza sartzeak kalte egiten dio kosta egiten zaion ikasleari» (EA: 12,2; A: 28,5; EAEK: 33,3; K: 21,5; EK: 4,4). 


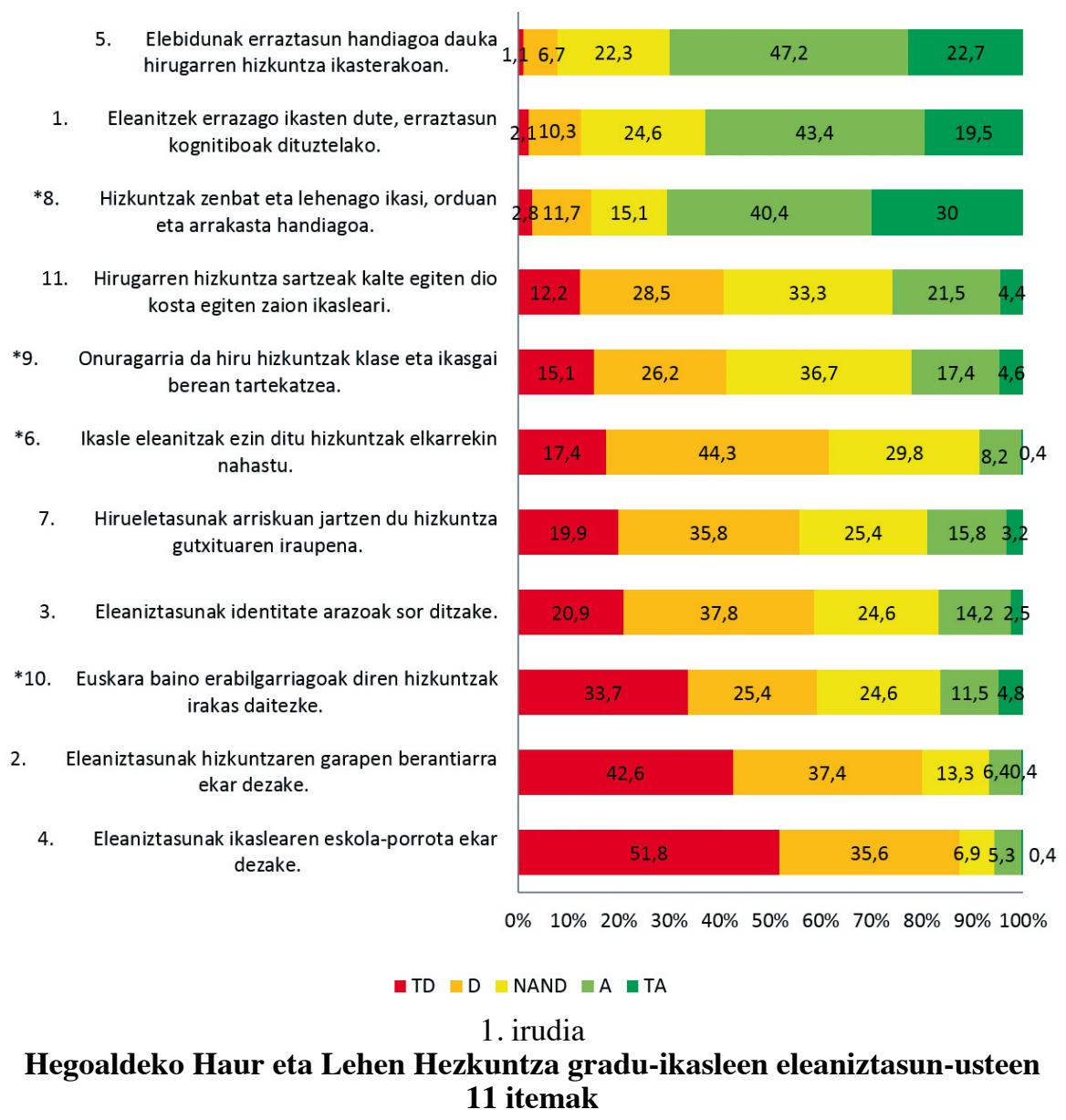

\section{EZTABAIDA ETA ONDORIOAK}

Honako azken atal honetan, ikerlaneko emaitzarik azpimarragarrienak ekarriko dira, arestian, teorian, azaldutako ikerketa eta ekarpen esanguratsuenekin eztabaidatu eta ikerketa-ondorio nagusiak idazteko. Eskuarteko ikerketak Hegoaldeko Haur eta Lehen Hezkuntza graduetako ikasleen eleaniztasun-usteak biltzea du xede. Ikerlanaren izaera kuantitatiboa izaki, galdetegien bitartez jaso dira etorkizuneko 564 irakasleren eleaniztasun-usteak honako bi helburuak erdiesteko: batetik, etorkizuneko irakasleen eleaniztasun-usteak oinarri eleanitz ala elebakarrekoak diren zehaztea; bestetik, eleaniztasun-uste zehatzei erreparatu eta horien ezaugarriak deskribatzea. 
Ikerketan bildutako datuek eta horien analisiak hainbat ezaugarri eta emaitza azaleratu dute. Aurretiaz eginiko ikerketekin ondorio amankomunak, kontrajarriak eta gehigarriak azalduko dira.

Hasteko, eleaniztasun-usteen hamaika itemen datu estatistiko-deskribatzaileak banaka eta orokorrean irakurriz gero, emaitzek iradokitzen dute Hegoaldeko Haur eta Lehen Hezkuntzako gradu-ikasleen usteak abegikorrak direla eleaniztasunarekiko. Gainera, emaitzek, iradoki ez ezik, berretsi ere egiten dute, berariaz sortutako eleaniztasun-usteen aldagaiaren batezbestekoak erakutsi bezala; izan ere, batezbestekoaren balio altuak adierazten $\mathrm{du}$, oro har, gradu-ikasleen eleaniztasun-usteak abegikorrak, positiboak eta oinarri eleanitzekoak direla, teorian azaldutako eredu holistikoekin bat eginik (Cenoz eta Gorter, 2014; Conteh eta Meier, 2014; May, 2013). Beraz, batezbestekoaren balioak eta usteen ikuspegi orokorrak baieztatzen du gradu-ikasleen uste-sistema positiboa dela eleaniztasunarekiko; edonola ere, irakurketa orokorretik usteen banakako xehetasunetara mugituko balitz fokua, analisi deskriptiboak hainbat kontrapuntu edo uste elebakar zehatz jartzen ditu mahai gainean.

Horien artean esanguratsua da etorkizuneko irakasleek adostasun-mailarik handiena adierazi diotela hizkuntza ahalik eta azkarren ikasteari, arrakasta handiagoarekin lotzen baitute. Euskal testuinguruan detektatutako uste elebakar hori Valentziako Komunitatean ere indartsua da, Portolés eta Martíren (2018) ikerketa-ondorioek erakutsi bezala. Hau da, Valentziako testuinguruan nola, Euskal Herrian ere etorkizuneko irakasleen usteak, oro har eleanitzak izanagatik ere, ikaskuntza goiztiarraren aldekoak dira. Gainera, hizkuntzen ikaskuntza goiztiarraren aldeko ustea sakon erroturik dagoelarik, gerta daiteke hori aldakaitzagoa izatea (Cabaroglu eta Roberts, 2000; Peacock, 2001).

Analisiek erakusten dute etorkizuneko irakasleen usteak positiboak direla eleaniztasunarekiko, eta posible da horren gakoa Jeoffrion et al.-en (2014) ekarpenak iradoki bezala haien hizkuntza-ezagutza izatea; izan ere, haien ikerketak dio hizkuntza gehiago eta maila altuan ezagutzeak onurak dakarzkiela eleaniztasun-usteei, hau da, positiboagoak eta abegikorragoak direla hizkuntza-ezagutza handitu ahala. Eta etorkizuneko-irakasle gehienek handia hiru hizkuntzetan garatzen dituzte hizkuntza-maila altuak: euskaran, espainolean eta ingelesean. Eta horrek nolabait izan dezake eraginik eleaniztasun-uste abegikorren eraketan.

Ikerketak islatutako beste ezaugarriei beha, argi dago etorkizuneko irakasleek bi uste arbuiatzen dituztela: batetik, eleaniztasunak ikaslea eskolaporrotera daramana eta, bestetik, eleaniztasunak hizkuntza-ikaskuntza moteltzen duena. Horiei ere batu beharko litzaieke gradu-ikasleek ez dutela hirueletasuna mehatxu bezala hartzen, hots, ez diola euskararen biziraupenari oztoporik sortzen ez eta ikaslearen identitatean arazorik sortzen ere. Gainera, etorkizuneko irakasleen erdiak baino gehiagok ez du uste euskara baino hizkuntza erabilgarriagorik irakats daitekeenik Hegoalden; bostenak 
baino gutxiagok uste du euskara baino hizkuntza erabilgarriagorik irakats daitekeenik. Eta horrek guztiak bat egiten du Cenoz eta Gorter-ek (2014) azaltzen duten Ikuspegi Eleanitza ereduarekin, Euskal Herriko ereduak eleaniztasunaren alde baina euskara erdigune ulertzen duenarekin.

Modu bertsuan, eztabaidaezina da gradu-ikasleek uste errotuak azaldu dituztela kognizioarekin. Esan nahi baita eleaniztasuna kognizioaren abiarazle gisa kontsideratzen dutela, izan ere, adostasun-mailarik handienak ondorengo bi uste nagusietan bildu dira: bat, elebidunek erraztasunak dituztela hirugarren hizkuntza ikasterakoan eta, bi, eleaniztunek kognizioa dela-eta hizkuntzak ikasteko erraztasuna dutela. Esku arteko ikerketak nabarmentzen du etorkizuneko irakasleen usteek elebitasuna eta eleaniztasuna onura gisa identifikatzen dituztela, eta gertakari horiek bat datoz arestian azaldutako eleaniztasun-eredu abegikorrekin (Cenoz eta Gorter, 2014; Conteh eta Meier, 2014; May, 2013).

Atal teorikoan jaso bezala, eleaniztun izatea abantaila da hizkuntza gehiago ikasteko orduan, eta ikerketa honen bitartez baiezta daiteke etorkizuneko irakasleen usteek bat egiten dutela eta lerrokaturik daudela elebitasuna eta eleaniztasuna hizkuntzak ikasteko kondizio hobe gisa ulertzearekin. Izan ere, literatura akademikoak baieztatu du, besteak beste, eleaniztunak hizkuntzak ikasteko baliabide gehiago duela, hizkuntzak ikasteko esperientzia aberatsagoa, funtzio kognitibo zailduagoak, hizkuntza-ezagutza sakonagoa, baliabide eta estrategia multzo zabalagoa (Barac et al., 2014; Bialystok, 2007; Cenoz, 2013; Jessner, 2008, 2016; Kalashnikova eta Mattock, 2014; Maluch eta Kempert, 2017; Moodie, 2016; Reder et al., 2013; Thomas-Sunesson et al., 2016).

Bestalde, emaitza kontrajarriak jaso dira eleaniztunak hizkuntzak tartekatzeko aukeraren inguruan. Alde batetik, badirudi etorkizuneko irakasleek ikuspegi malguagoa dutela eleaniztunaren hizkuntzak tartekatzeko joerarekin; izan ere, hamarretik seik desadostasuna adierazi diote hizkuntzak tartekatzearen debekuari, eta soilik batek ikusiko luke begi onez. Emaitza hori bat etorriko litzateke hizkuntzen arteko mugak malgu eta Hizkuntza-Ezagutza Osoa ekintza komunikatiboaren menpe jartzeko eredu eta proposamenekin, Ikuspegi Eleanitzarekin, alegia (Blackledge eta Creese, 2010; Cenoz eta Gorter, 2014, 2015; Conteh eta Meier, 2014; Grosjean, 1985; May, 2013). Halere, datuek iradokitzen dute oraindik ere arrotz egiten zaiela eleaniztunak hain berezko dituen hizkuntzen arteko erabilera tartekatua eskola-testuinguruan txertatzea; izan ere, hamarretik lauk kontrako ustea adierazi du eta soilik bostenak ikusiko luke begi onez euskal hezkuntzan euskara, espainola eta ingelesa hirurak klase eta ikasgai berean tartekatzea, hots, translanguagingaren aplikazioa (Cenoz eta Gorter, 2019; García, 2009; García eta Wei, 2014).

Talaia honetatik, ikerlanak etorkizuneko irakasleak jarduera eleanitzetan hezteko beharra azpimarratzen du, bat eginik aurretiaz makina bat adituk egindako aldarri eta eskaerekin (Blackledge eta Creese, 2010; Ce- 
noz eta Gorter, 2014, 2019; Conteh eta Meier, 2014; Jessner, 2016; May, 2013). Baina, zer da irakasleak jarduera eleanitzetan trebatzea? Testuinguru eleanitzek eta ikasle eleaniztunek berezkoak dituzten ezaugarriak hautemateko lanean hezi eta horiek baliatzen irakastea litzateke; hots, ikasleen hizkuntza-ezagutza baliaturik, hizkuntzen arteko konparazioak egitea, egitura linguistikoak erkatzea, hizkuntzen gaineko gogoetak bultzatzea, kontzientzia metalinguistikoaren erabileran sakontzea eta hiztun eleanitzek berezkoak dituen hizkuntzen arteko jauziak modu pedagogiko eta ordenatuan baliatzea hizkuntzen ikaskuntza modu eraginkorragoan ikasteko.

Teorian azaldu moduan, formazio-ikastaroak berariaz diseinatu beharko lirateke, irakasleen usteak ikuspegi eleanitzetan doitu eta jarduera nahiz praktika eleanitzetan hezi ahal izateko. Izan ere, literatura akademikoak erakutsi du, hainbat uste aldakaitz eta iraunkor gorabehera (M. Borg, 2005; Peacock, 2001), posible dela etorkizuneko irakasleen usteak eleaniztasunean hezi eta irakas-jarduera eleanitzak bultzatzea (Cabaroglu eta Roberts, 2000; Fischer eta Lahmann, 2020; Jeoffrion et al., 2014; Moodie, 2016; Sheridan, 2016; Yuan eta Lee, 2014).

\section{ERREFERENTZIAK}

Aiestaran, J. (2012). Attitudes towards bilingualism and Basque in Rioja Alavesa. Euskal Herriko Unibertsitatea.

Amonarriz, K., eta Martinez de Lagos, I. (2017). Bidegurutzetik ateratzeko palankak. BAT Soziolinguistika Aldizkaria, 2(103), 27-38. or.

Arocena, E. (2017). Multilingual education: teachers' beliefs and language use in the classroom. Euskal Herriko Unibertsitatea.

Barac, R., Bialystok, E., Castro, D. C., eta Sanchez, M. (2014). The cognitive development of young dual language learners: A critical review. Early Childhood Research Quarterly, 29(4), 699-714. or. https://doi.org/https://doi. org/10.1016/j.ecresq.2014.02.003

Bialystok, E. (2007). Cognitive Effects of Bilingualism: How Linguistic Experience Leads to Cognitive Change. International Journal of Bilingual Education and Bilingualism, 10(3), 210-223. or. https://doi.org/10.2167/beb441.0

Blackledge, A., eta Creese, A. (2010). Multilingualism: A Critical Perspective. Continuum.

Borg, M. (2005). A Case Study of the Development in Pedagogic Thinking of a Pre-Service Teacher. Tesl-Ej, 9(2), 1-30. or.

Borg, S. (2015). Teacher cognition and language education: Research and practice. Bloomsbury Publishing.

Cabaroglu, N., eta Roberts, J. (2000). Development in student teachers' pre-existing beliefs during a 1-year PGCE programme. System, 28(3), 387-402. or. https://doi.org/10.1016/S0346-251X(00)00019-1

Cenoz, J. (2009). Towards multilingual education: Basque Educational Research from an International Perspective. Multilingual Matters. 
Hegoaldeko Haur eta Lehen Hezkuntza graduetako ikasleen eleaniztasun-usteak

Cenoz, J. (2011). The influence of bilingualism on third language acquisition: Focus on multilingualism. Language Teaching, 46(1), 71-86. or. https://doi. org/10.1017/S0261444811000218

Cenoz, J. (2013). The influence of bilingualism on third language acquisition: Focus on multilingualism. Language Teaching, 46(1), 71-86. or. https://doi. org/10.1017/S0261444811000218

Cenoz, J., eta Gorter, D. (2014). Focus on Multilingualism as an Approach in Educational Contexts (pp. 239-254). https://doi.org/10.1007/978-94-0077856-6_13

Cenoz, J., eta Gorter, D. (2015). Towards a Holistic approach in the Study of Multilingual Education. https://www.researchgate.net/publication/306158117_ Towards_a_Holistic_approach_in_the_study_of_multilingual_education.

Cenoz, J., eta Gorter, D. (2019). Multilingualism, Translanguaging, and Minority Languages in SLA. Modern Language Journal, 103, 130-135. or. https://doi. org/10.1111/modl.12529

Conteh, J., eta Meier, G. (2014). TheMultilingual Turn in Languages Education. Multilingual Matters. https://doi.org/https://doi.org/10.21832/9781783092246

Dendaluze, I. (2002). Ciencias sociales e invest igación. Ciencias Sociales e Investigación. XV Congreso de Estudios Vascos: Euskal Zientzia Eta Kultura, Eta Sare Telematikoak, 1139-1158, or.

Erdocia, I. (2018). Current Issues in Language Planning Medium of instruction ideologies: accommodation of multilingualism in the bilingual regime of $\mathrm{Me}$ dium of instruction ideologies. Current Issues in Language Planning, 20(3), 1-25. or. https://doi.org/10.1080/14664208.2018.1503457

Etxebarrieta, G. R., Pérez-izaguirre, E., eta Langarika-Rocafort, A. (2020). Teaching minority languages in multiethnic and multilingual environments: Teachers' perceptions of students' attitudes toward the teaching of basque in compulsory education. Education Sciences, 10(2). https://doi.org/10.3390/ educsci10020025

Fischer, N., eta Lahmann, C. (2020). Pre-service teachers' beliefs about multilingualism in school: an evaluation of a course concept for introducing linguistically responsive teaching. Language Awareness, 19(2), 114-133. or. https:// doi.org/10.1080/09658416.2020.1737706

Garcia, L., Arratibel, N., eta Irizar, A. (2017). Euskararen ezagutza eta erabilera binomioa: Mondragon Unibertsitateko Humanitate eta Hezkuntza Zientzien fakultateko 1. mailako ikasleak ulertzeko gakoak. BAT Soziolinguistika Aldizkaria, 4(105), 163-199. or.

García, O. (2009). Bilingual education in the 21st century: A global perspective. Wiley-Blackwell.

García, O., eta Wei, L. (2014). Language, Bilingualism and Education, (6-62. or). https://doi.org/10.1057/9781137385765_4

Gilakjani, A. P., eta Sabouri, N. B. (2017). Teachers' Beliefs in English Language Teaching and Learning: A Review of the Literature. English Language Teaching, 10(4), 78 or. https://doi.org/10.5539/elt.v10n4p78

Gorter, D., eta Cenoz, J. (2017). Language education policy and multilingual assessment. Language and Education, 31(3), 231-248. or. https://doi.org/10.108 0/09500782.2016.1261892 
Grosjean, F. (1985). The bilingual as a competent but specific speaker-hearer. Journal of Multilingual and Multicultural Development, 6(6), 467-477. or. https://doi.org/10.1080/01434632.1985.9994221

Grosjean, F. (2010). Bilingualism, biculturalism, and deafness. International Journal of Bilingual Education and Bilingualism, 13(2), 133-145. or. https://doi. org/10.1080/13670050903474051

Inceçay, G. (2011). Pre-service teachers' language learning beliefs and effects of these beliefs on their practice teaching. Procedia - Social and Behavioral Sciences, 15, 128-133. or. https://doi.org/10.1016/j.sbspro.2011.03.061

Jeoffrion, C., Marcouyeux, A., Starkey-perret, R., Narcy-combes, F., Birkan, I., Jeoffrion, C., Marcouyeux, A., eta Starkey-perret, R. (2014). From multilingualism to plurilingualism: university students' beliefs about language learning in a monolingual context. Language, Culture and Curriculum, 27(1), 8-26. or. https://doi.org/10.1080/07908318.2014.887724

Jessner, U. (2008). Teaching third languages: Findings, trends and challenges. Language Teaching, 41(1), 15-56. or. https://doi.org/DOI: 10.1017/ S0261444807004739

Jessner, U. (2016). Multicompetence Approaches to Language Proficiency Development in Multilingual Education BT - Bilingual and Multilingual Education. O. Garcia, A. Lin, eta S. May (arg.), (1-13). Springer International Publishing. https://doi.org/10.1007/978-3-319-02324-3_10-1

Kalaja, P., eta Barcelos, A. M. F. (2019). Learner Beliefs in Second Language Learning. In The Encyclopedia of Applied Linguistics, 1-7. or. https://doi.org/ doi:10.1002/9781405198431.wbeal0082.pub2

Kalashnikova, M., eta Mattock, K. (2014). Maturation of executive functioning skills in early sequential bilingualism. International Journal of Bilingual Education and Bilingualism, 17, 111-123. or. https://doi.org/10.1080/13670050.2 012.746284

Maluch, J. T., eta Kempert, S. (2017). Bilingual profiles and third language learning: the effects of the manner of learning, sequence of bilingual acquisition, and language use practices. International Journal of Bilingual Education and Bilingualism, 22(7), 1-13. or. https://doi.org/10.1080/13670050.2017.1322036

May, S. (2013). The Multilingual Turn: Implications for SLA, TESOL, and Bilingual Education. Taylor \& Francis. https://books.google.es/books?id=_ WoqAAAAQBAJ

Moodie, I. (2016). The anti-apprenticeship of observation: How negative prior language learning experience influences English language teachers' beliefs and practices. System, 60, 29-41. or. https://doi.org/10.1016/j.system.2016.05.011

Pajares, M. F. (1992). Teachers' beliefs and educational research: Cleaning up a messy construct. Review of Educational Research, 62(3), 307-332. or.

Peacock, M. (2001). Pre-service ESL teachers' beliefs about second language learning: a longitudinal study. System, 29(2), 177-195. or. https://doi.org/http:// doi.org/10.1016/S0346-251X(01)00010-0

Portolés, L., eta Martí, O. (2018). Teachers ' beliefs about multilingual pedagogies and the role of initial training of initial training. International Journal of Multilingualism, 17(2), 248-264. or. https://doi.org/10.1080/14790718.2018.1515 206 
Reder, F., Marec-Breton, N., Gombert, J. E., eta Demont, E. (2013). Second-language learners' advantage in metalinguistic awareness: A question of languages' characteristics. British Journal of Educational Psychology, 83(4), 686702. or. https://doi.org/10.1111/bjep.12003

Sheridan, L. (2016). Examining Changes in Pre-service Teachers 'Beliefs of Pedagogy. Australian Journal of Teacher Education, 41(3), 1-20 or. https://doi. org/10.14221/ajte.2016v41n3.1

Taber, K. S. (2018). The Use of Cronbach's Alpha When Developing and Reporting Research Instruments in Science Education. Research in Science Education, 48(6), 1273-1296. or. https://doi.org/10.1007/s11165-016-9602-2

Thomas-Sunesson, D., Hakuta, K., eta Bialystok, E. (2016). Degree of bilingualism modifies executive control in Hispanic children in the USA. International Journal of Bilingual Education and Bilingualism, 21, 1-10. or. https://doi. org/10.1080/13670050.2016.1148114

Yuan, R., eta Lee, I. (2014). Pre-service teachers ' changing beliefs in the teaching practicum: Three cases in an EFL context. System, 44, 1-12. or. https://doi. org/10.1016/j.system.2014.02.002

Zheng, H. (2013). Teachers' beliefs and practices: a dynamic and complex relationship. Asia-Pacific Journal of Teacher Education, 41(3), 331-343. or. https://doi.org/10.1080/1359866X.2013.809051 